\title{
Leukocyte blood composition of Naturix natrix (Serpentes: Colubridae) in the Mordovian State Nature Reserve (Russia)
}

\author{
E. B. Romanova ${ }^{1 凶}$, E. I. Solomaykin ${ }^{1}$, A. G. Bakiev ${ }^{2}$, R. A. Gorelov ${ }^{2}$ \\ ${ }^{1}$ Lobachevsky State University of Nizhni Novgorod \\ 23 Gagarin Avenue, Nizhni Novgorod 603950, Russia \\ ${ }^{2}$ Samara Federal Research Center of RAS, \\ Institute of Ecology of the Volga River Basin of Russian Academy of Sciences \\ 10 Komzina St., Togliatti 445003, Russia
} Article info
Original Article
https://doi.org/10.18500/1814-6090-2021-21-
1-2-18-29

Received 12 April 2021, revised 27 April 2021, accepted 12 May 2021

\begin{abstract}
The state of the grass snake (Natrix natrix) population in the Mordovian State Nature Reserve was assessed using the hematological approach. The leukocyte blood count was estimated together with calculation of the associated leukocyte indices (neutrophil:lymphocyte $(\mathrm{N}: \mathrm{L})$, eosinophil:lymphocyte (E:L), heterophil:eosinophil (H/E) and heterophil:lymphocyte $(\mathrm{H}: \mathrm{L})$ ratios). The surface area of leukocytes (heterophils, basophils, eosinophils, azurophils, monocytes, and lymphocytes) was measured. The leukocyte blood composition of Natrix natrix was characterized by the predominance of agranulocytes, and the granulocyte fraction was 31$37 \%(u=1.99, p=0.04)$. The population pattern of the leukocyte blood composition of Natrix natrix was as follows: heterophils $-8.07 \pm 0.6 \%$, basophils $-12.33 \pm 0.95 \%$, eosinophils $8.33 \pm 0.65 \%$, azurophils - $5.25 \pm 0.53 \%$, monocytes - $9.77 \pm 0.42 \%$, and lymphocytes $56.22 \pm 1.7 \%$. According to the averaged area, the leukocytes were arranged in the following order: eosinophils - monocytes - azurophils, basophils - heterophils - lymphocytes. The diameter of the largest cells (eosinophils) was $(17.5 \pm 2.42) \mu \mathrm{m}$. The smallest lymphocytes had diameters within $(7.22 \pm 1.21) \mu \mathrm{m}$. The absence of any differences in the quantitative content of all types of granulocytes and agranulocytes in the blood of the grass snake from different parts of the reserve indicated a comparable level of impact and the identity of the physiological mechanisms of adaptation that occur in the body of animals in protected habitat conditions. Most of the leukocyte integral indices revealed the same type of variability in the parameters of the white blood cell system of the Natrix natrix in three areas of the reserve, with the exception of an increased value of the heterophiles/lymphocytes ratio in the sample from the village Pushta. The increase in this indicator made it possible to draw a conclusion about the stress effect on the individuals of this sample. The principal component method was used to differentiate the samples of the grass snake with a more complete quantitative description of the leukocyte composition of the objects of study; the results obtained are presented in a visual, integrated and generalized form. The use of the principal component method made it possible to combine samples of Natrix natrix with similar indicators of leukocyte composition, as well as to identify a population of Natrix natrix that differs in its indicators in the urbanized territory of the Samara region. The blood pattern and the dynamics of blood leukocyte indices reflected the active response of the Natrix natrix body to the complex of environmental factors of the habitat on the territory of the Mordovian State Nature Reserve.
\end{abstract}

Keywords: Natrix natrix, WBC (white blood cells), leukocytal index, peripheral blood

For citation: Romanova E. B., Solomaykin E. I., Bakiev A. G., Gorelov R. A. Leukocyte blood composition of Naturix natrix (Serpentes: Colubridae) in the Mordovian State Nature Reserve (Russia). Current Studies in Herpetology, 2021, vol. 21, iss. 1-2, pp. 18-29 (in Russian). https://doi.org/10.18500/1814-6090-2021-21-1-2-18-29
This article is an open access article distributed under the terms and conditions of the Creative Commons Attribution 4.0 License
Astradamov V. I., Kasatkin S. P., Kuznetsov V. A., Potapov S. K., Ruchin A. B., Silaeva T. B. 2002. Materials for the inventory of amphibians and reptiles of the Republic of Mordovia. In: Materialy $k$ kadastru amfibii $i$ reptilii basseina Srednei Volgi [Materials for the InvenProceeding of the Ukranian Herpetological Society, 2014, no. 5, pp. 3-11 (in Russian).

\footnotetext{
${ }^{\square}$ Corresponding author. Department of Ecology of Institute of Biology and Biomedicine, Lobachevsky State University of Nizhni Novgorod, Russia.

ORCID and e-mail addresses: Elena B. Romanova: https://orcid.org/0000-0002-1925-7864, romanova@ibbm.unn.ru; Evgeny I. Solomaykin: https:// orcid.org/0000-0003-4030-8272, e7v4gen5iy@yandex.ru; Andrey G. Bakiev: https://orcid.org/0000-0002-0338-2740, herpetology@list.ru; Roman A. Gorelov: https://orcid.org/0000-0002-0207-2951, gorelov.roman@mail.ru.
} 
tory of Amphibians and Reptiles of the Middle Volga Basin]. Nizhni Novgorod, Ecocenter "Dront" Publ., 2002, pp. 167-185 (in Russian).

Bakiev A. G., Garanin V. I., Litvinov N. A., Pavlov A. V., Ratnikov V. Ju. Zmei Volzhsko-Kamskogo kraia [Snakes of Volga-Kama Region]. Samara, Izdatel'stvo Samarskogo nauchnogo tsentra RAN, 2004. 192 p. (in Russian)

Bakiev A. G., Malenev A. L., Zaitseva O. V., Shurshina I. V. 2009. Zmei Samarskoi oblasti [Snakes of the Samara Region]. Togliatti, Kassandra Publ., 170 p. (in Russian).

Vorobyova A. S. Comparative characteristics of peripheral blood of snakes of the Volga basin. Actual Problems of Herpetology and Toxinology, 2007, iss. 10, pp. 25-30 (in Russian).

Gordeev D. A. Features of the distribution, biology, ecology and morphology of Natrix natrix (Linneaus, 1758) of the Volgograd region. Izvestia of Samara Scientific Center of the Russian Academy of Sciences, 2012, vol. 14, no. 1, pp. 150-153 (in Russian).

Idrisova L. A. Aberrations in pholidosis of reptiles: Regularities in deviations topography. University Proceedings. Volga Region. Natural Sciences, 2019, no. 2 (26), pp. 60-66 (in Russian). https://doi.org/ 10.21685/2307-9150-2019-2-6

Eliseeva I. N., Enivatova D. A. Ecological and biological features of the common snake Natrix natrix in the Mordovian State Reserve. Proceedings of the $\mathrm{Na}$ tional Park “Smolny”, 2020, vol. 4, pp. 110-121 (in Russian).

Klenina A. A., Bakiev A. G. Egg volume in clutches of Natrix natrix and $N$. tessellata: Work on errors. Principles of Ecology, 2015, vol. 4, no. 4, pp. 11-21 (in Russian). https://doi.org/ 10.15393/j1.art.2015.4602

Klenina A. A., Gordeev D. A., Prilipko S. K. Nutrition of the genus Natrix in the Volgograd Region. Izvestia of Samara Scientific Center of the Russian Academy of Sciences, 2015, vol. 17, no. 4, pp. 718- 720 (in Russian).

Lada G. A., Levin A. N., Artemova L. V., Rybkina N. S. On the evaluation of environmental condition by the level of fluctuating asymmetry in anuran amphibian of lake frog (Rana ridibunda) as an example. Principles of Ecology, 2012, vol. 1, no. 3, pp. 82-88 (in Russian). https://doi.org/10.15393/j1.art.2012.1541

Lisnichaya Y. N., Yefimov V. G. Feature's study morphological composition of blood reptiles. Science and Technology Bulletin of Scientific Research Center for Biosafety and Environmental Control of Agro-Industrial Complex, 2014, vol. 2, no. 1, pp. 61-74 (in Russian).

Loboda E. I. Morphological and cytochemical characteristics of white blood cells in representatives of some species of cold-blooded vertebrates. Vestnik Zoologii, 1998, vol. 32, no. 3, pp. 54- 57 (in Russian).

Pavlov A. V. Key moments of reptile hematology: features of the assessment of the leukocyte part of blood. Proceedings. Volga Region. Natural Sciences, 2019, no. 1 (25), pp. 138-152 (in Russian). https://doi.org/ 10.21685/2307-9150-2019-1-14

Pavlov A. V., Yusupov R. Kh. Blood system. In: Gadiuki (Reptilia: Serpentes: Viperidae: Vipera) Volzhskogo basseina [Vipers (Reptilia: Serpentes: Viperidae: Vipera) of the Volga Basin]. Togliatti, Kassandra Publ., 2015, pt. 1, pp. 137-155 (in Russian).

Peskova T. Yu. Adaptatsionnaia izmenchivost' zemnovodnykh $v$ antropogenno zagriaznennoi srede [Adaptive Variability of Amphibians in Anthropogenically Polluted Environment]. Diss. Dr. Sci. (Biol.). Togliatti, 2004. 284 p. (in Russian).

Romanova E. B., Nikolaev V. Yu., Bakiev A. G., Klenina A. A. The leukogram of grass snake (Natrix natrix) and diced snake (N. tessellata) in national park "Samarskaya Luka". Izvestia of Samara Scientific Center of the Russian Academy of Sciences, 2014, vol. 16, no. 1, pp. 152-155 (in Russian).

Romanova E. B., Nikolaev V. Yu., Bakiev A. G., Klenina A. A. Features of the leukocyte composition of blood of females of common snake (Natrix natrix) and water snake ( $N$. tessellata) (Reptilia: Colubridae) of the Samara region. Current Studies in Herpetology, vol. 15, iss. 1-2, pp. 69-76 (in Russian).

Romanova E. B., Solomaikin E. I., Bakiev A. G., Gorelov R. A., Klenina A. A. Immunohematological indicators of poisonous and non-toxic snakes in the Volga basin with different anthropogenic transformations. Izvestia of Samara Scientific Center of the Russian Academy of Sciences, 2017, vol. 19, no. 2, pp. 54-61 (in Russian).

Ruchin A. B., Ryzhov M. K. Amphibians and reptiles of Mordovia: An ecological and faunistic survey. Povolzhskiy Journal of Ecology, 2003, no. 2, pp. 195-201 (in Russian).

Ruchin A. B., Lapshin A. S., Ryzhov M. K. On snake distribution in Mordovia region. Current Studies in Herpetology, 2005, vol. 7, iss. 3-4, pp. 93-98 (in Russian).

Ruchin A. B., Ryzhov M. K., Lobachev E. A. Distribution and morphometric characteristics of the common snake (Natrix natrix) from Mordovia. In: Zmei Vostochnoi Evropy [Serpents of Eastern Europe]. Togliatti, Institut ekologii Volzhskogo basseina RAN Publ., 2003. pp. 70-72 (in Russian).

Sokolina F. M., Pavlov A. V., Yusupov R. Gematologiia presmykaiushchikhsia. Metodicheskoe posobie $k$ kursu gerpetologii, bol'shomu praktikumu i seminaram [Reptile Hematology: The Guidance Manual for Herpetology Course, Long-Term Practical Work, and Seminars]. Kazan, Kazanskii universitet Publ., 1997. 31 p. (in Russian).

Tabachishin V. G., Tabachishina I. E. Distribution and ecology features of Natrix natrix in the north of the Lower Volga region. Povolzhskiy Journal of Ecology, 2002, no. 2, pp. 179-183 (in Russian).

Khairutdinov I. Z., Sokolina F. M. Kharakteristika krovi reptilii i ee sviaz's usloviiami sredy obitaniia [Reptile Blood Characteristics and their Connection with En- 
vironmental Conditions]. Kazan, Kazanskii universitet Publ., 2010. 44 p. (in Russian).

Chuguevskaya N. M. Uzhi (Serpentes, Colubridae, Natrix) Volzhskogo basseina: Ekologiia i okhrana [Snakes (Serpentes, Colubridae, Natrix) of the Volga basin: Ecology and conservation]. Thesis Diss. Cand. Sci. (Biol.). Togliatti, 2005. 20 p. (in Russian).

Shlyakhtin G. V., Tabachishin V. G., Zavyalov E. V. Nutrition ecology of common snake (Natrix natrix) in the north of the Lower Volga region. Current Studies in Herpetology, 2005, vol. 3-4, pp. 111-116 (in Russian).

Arican H., Cicek K. Morphology of peripheral blood cells from various species of Turkish herpetofauna. Acta Herpetologica, 2010, vol. 5, no. 2, pp. 179-198. https://doi.org/10.13128/Acta_Herpetol-8526

Bakiev A., Kirillov A., Mebert K. Diet and Parasitic Helminths of Dice Snakes from the Volga Basin, Russia. Mertensiella, 2011, vol. 18, pp. 325-329.

Campbell T. W. Clinical pathology of reptiles. Reptile Medicine and Surgery. 2nd ed. St. Louis (MO), Saunders Publishing, 2006, pp. 453-470.

Coico R., Sunshine G., Benjamini E. Immunology: A Short Course. Hoboken, Wiley-Liss Publications, 2003. $500 \mathrm{p}$.

Davis A. K., Maney D. L., Maerz J. The use of leukocyte profiles to measure stress in vertebrates: A review for ecologists. Functional Ecology, 2008, vol. 22, pp. 760767. https://doi.org/10.1111/j.1365-2435.2008.01467.x

Davis A. K., Cook K. C., Altizer S. Leukocyte profiles of House Finches with and without mycoplasmal conjunctivitis, a recently emerged bacterial disease. EcoHealth, 2004, vol. 1, iss. 4, pp. 362-373 https://doi.org/ 10.1007/ s10393-004-0134-2
International Guiding Principles for Biomedical Research Involving Animals. Geneva, Switzerland, Council for International Organization of Medical Sciences Publ., 2012. 4 p.

Kluger M. J., Ringler D. H., Anver M. R. Fever and survival. Science, 1975, vol. 188, pp. 166-168.

Litvinov N., Bakiev A., Mebert K. Thermobiology and microclimate of the Dice snake at its Northern range limit in Russia. Mertensiella, 2011, vol. 18, pp. 330-335.

Merchant M., Williams S., Trosclair P. L., Elsey R. M., Mills K. Febrile response to infection in the American alligator (Alligator mississippiensis). Comparative Biochemistry and Physiology, 2007, vol. 148, iss. 4, pp. 921-925. https://doi.org/10.1016/j.cbpa.2007.09.016

Oros J., Casal A. B., Arencibia A. Microscopic studies on characterization of blood cells of endangered sea tuttles. Microscopy: Science, Technology, Application and Education, 2010, vol. 1, pp. 75-84.

Salakij C., Salakij J., Chanhome L. Comparative hematology, morphology and ultrastructure of blood cells in Monocellate cobra (Naja kaouthia), Siamese spitting cobra (Naja siamensis) and Golden spitting cobra (Naja sumatrana). Kasetsart Journal - Natural Science, 2002, vol. 36, pp. 291-300.

Stacy N. I., Alleman A. R., Sayler K. A. Diagnostic hematology of reptiles. Clinics in Laboratory Medicine, 2011, vol. 31, iss. 1, pp. 87-108. https://doi.org/ 10.1016/j.cll.2010.10.006

Tavares-Dias M., Oliveira-Junior A. A., Marcon J. L. Methodological limitations of counting total leukocytes and thrombocytes in reptiles (Amazon turtle, Podocnemis expansa): An analysis and discussion. Acta Amazonica, 2008, vol. 38 , no. 2, pp. 351-356. 